\title{
Review Article \\ Resistance to Phomopsis Seed Decay in Soybean
}

\author{
Shuxian $\mathrm{Li}^{1}$ and Pengyin Chen ${ }^{2}$ \\ ${ }^{1}$ United States Department of Agriculture-Agricultural Research Service, Crop Genetics Research Unit, Stoneville, MS 38776, USA \\ ${ }^{2}$ University of Arkansas, Fayetteville, AR 72701, USA \\ Correspondence should be addressed to Shuxian Li; shuxian.li@ars.usda.gov
}

Received 22 November 2012; Accepted 10 December 2012

Academic Editors: J. A. Casaretto, E. Perez-Artes, and J. Ransom

Copyright (C) 2013 S. Li and P. Chen. This is an open access article distributed under the Creative Commons Attribution License, which permits unrestricted use, distribution, and reproduction in any medium, provided the original work is properly cited.

\begin{abstract}
Phomopsis seed decay (PSD) of soybean is caused primarily by the fungal pathogen Phomopsis longicolla Hobbs along with other Phomopsis and Diaporthe spp. This disease causes poor seed quality and suppresses yield in most soybean-growing countries. Infected soybean seeds can be symptomless, but are typically shriveled, elongated, cracked, and have a chalky white appearance. Development of PSD is sensitive to environmental conditions. Hot and humid environments favor pathogen growth and disease development. Several control strategies have been used to manage PSD and reduce its impact; however, the use of resistant cultivars is the most effective method for controlling PSD. Efforts have been made to identify sources of PSD resistance in the past decades. At least 28 soybean lines were reported to have certain levels of PSD resistance in certain locations. Inheritance of resistance to PSD has been studied in several soybean lines. In this paper, general information about the disease, the causal agent, an overview of research on evaluation and identification of sources of resistance to PSD, and inheritance of resistance to PSD are presented and discussed.
\end{abstract}

\section{Introduction}

Phomopsis seed decay (PSD) of soybean, Glycine max (L.) Merrill, is caused primarily by the fungal pathogen Phomopsis longicolla Hobbs et al. [1] along with other Phomopsis and Diaporthe spp. This disease causes poor seed quality and suppresses yield in most soybean-growing countries, especially in the mid-southern region of the United States $[2,3]$. PSD severely affects soybean seed quality due to reduction in seed viability and oil content, alteration of seed composition, and increased frequencies of moldy and/or split beans [47]. Development of PSD is sensitive to environmental conditions. Hot and humid environmental conditions, especially during the period from the pod fill through harvest stages, favor pathogen growth and disease development [2, 8-11].

PSD has been reported to cause significant economic losses $[4,12]$. Annual yield loss caused by PSD in the United States from 1996 to 2007 ranged from 0.38 to 0.43 million metric tons (MMT) [13]. PSD has been exacerbated in recent years because of the use of the early soybean production system (ESPS), which generally involves planting of early-maturing cultivars in April to avoid the late-season droughts typical of the region in the mid-southern USA [14].
Unfortunately, seed infection by $P$. longicolla was high in some cultivars that matured in July or August, when high temperatures and high humidity were conducive to PSD development [15]. In 2009, due to the prevalence of hot and humid environments from pod fill to harvest in the southern United States, PSD caused over 0.33 MMT loss in 16 states [16]. The identification and utilization of sources of resistance to PSD for breeding programs are important, since planting resistant cultivars would be one of the most economical and effective ways to manage the disease $[2,10,17-20]$.

The research on PSD including pathogen characterization, germplasm screening, and genetic resistance in the USA were summarized and presented at the World Soybean Research Conference VII in 2009 [21].

\section{Disease Symptoms and the Causal Pathogens}

Soybean seeds infected by $P$. longicolla can be symptomless [22] but are typically shriveled, elongated, or cracked, and often appear chalky white (Figure 1). Infected seeds either fail to germinate or germinate more slowly than healthy seeds. 


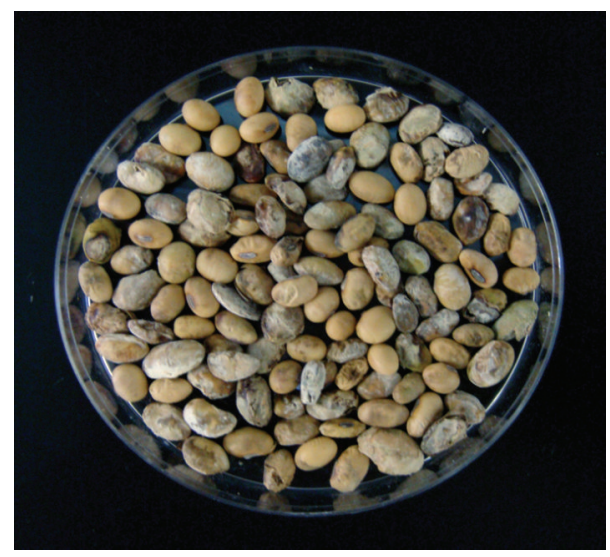

Figure 1: Phomopsis seed decay caused primarily by the fungus Phomopsis longicolla.

Seed infection causes pre- and postemergence damping-off, and under severe conditions, stands can be reduced to the point of lowering yield $[2,3,10,23]$. Soybean pods can be infected at any time after they form.

The culture morphology of $P$. longicolla on potato dextrose agar is floccose, dense, and white with occasional greenish yellow areas. The undersides of cultures are colorless with large, black, spreading stromata (Figure 2). P. longicolla has been found to account for more than $85 \%$ of all Phomopsis seed infection [1]. This pathogen is primarily known as a seedborne pathogen, but it can be isolated from all parts of plant and is the predominant species isolated from diseased plants $[24,25]$, and from both discolored and nondiscolored mature soybean stems [26]. It has been found that P. longicolla is more prevalent in seeds from pods at the bottom of plant than at the top [23].

Although P. longicolla is the primary cause of PSD, other fungal members in the Diaporthe-Phomopsis complex may also be associated with PSD [23]. The Diaporthe-Phomopsis complex consists of $P$. longicolla and three varieties of Diaporthe phaseolorum (Cooke and Ellis) Sacc. (anamorph P. phaseoli (Desmaz) Sacc.), in which D. phaseolorum var. caulivora K. L. Athow and R. M. Caldwell and D. phaseolorum var. meridionalis Fernández cause stem canker of soybean while D. phaseolorum var. sojae (S. G. Lehman) Wehmeyer causes pod and stem blight $[2,27,28]$. P. longicolla differs from others in the Diaporthe-Phomopsis complex in its morphology. It also does not have a known teleomorph [1].

Understanding the nature and the variability of the pathogen is essential for understanding its population diversity, and such information will also be important for selecting isolates to develop broad-based disease resistance in soybean lines. However, there are only a few publications on the variability of aggressiveness on soybean among P. longicolla isolates. The term "pathogen aggressiveness," as used in this paper, is based on colonization of and damage to soybean $[29,30]$.

In a greenhouse study, Li et al. [32] evaluated 48 isolates from the National Soybean Pathogen Collection Center at the
University of Illinois at Urbana-Champaign using the cutstem inoculation method. Isolates used in this study included 35 P. longicolla isolates from soybean in eight states in the U.S., along with the type culture of P. longicolla (Fau 600, ATCC 64802) from soybean in Ohio [1], two P. longicolla isolates from velvetleaf in Illinois [33], and 11 other Phomopsis spp. isolates from other hosts in four states in the USA, as well as from Canada and Costa Rica. Besides morphological identification, the identities of the isolates were also verified by sequence analysis of the ITS regions and the mitochondrial small subunit rRNA genes ([33-35] (http://nt.arsgrin.gov/fungaldatabases/specimens/specimens.cfm)).

There were significant $(P \leq 0.0001)$ differences among isolates based on stem length and stem lesion length. The P. longicolla soybean isolate PL16, from Mississippi, caused the shortest stem length while the nonsoybean isolate P9, from Illinois, caused the greatest stem lesion length. The type isolate of P. longicolla, PL31 (Fau 600), was one of the three most aggressive isolates among the 48 isolates evaluated. The velvetleaf isolate P9 from Illinois was the most aggressive among 13 isolates from nonsoybean hosts. This study provided the first evaluation of aggressiveness of $P$. longicolla isolates from different geographic origins and the first demonstration that Phomopsis spp. isolated from cantaloupe, eggplant, and watermelon were able to infect soybean [32]. This study provided important information that is very useful for selecting isolates for screening in breeding broad-based resistance in soybean lines to PSD.

\section{Evaluation and Identification of Sources for Resistance to PSD}

Screening soybean lines for resistance to PSD is the first step toward developing PSD-resistant cultivars. Efforts have been made to identify sources of PSD resistance in the past decades. In a 4-year project carried out by the USDAARS scientists, seeds of 208 representative maturity group V soybean plant introductions (PIs) obtained from the USDA Soybean Germplasm Collection in 2006 were plated on cultural medium and assayed for the percentage of Phomopsis seed infection [31]. The general procedure for seed plating is shown in Figure 3. Briefly, the seeds were first surfacedisinfected in $0.5 \%$ sodium hypochlorite for $3 \mathrm{~min}$, rinsed in sterile distilled water, and then placed on potato dextrose agar that was acidified ( $\mathrm{pH} 4.8$ ) with $25 \%$ lactic acid (APDA). Five seeds per Petri dish and five Petri dishes per sample were used. After 4 days of incubation at $24^{\circ} \mathrm{C}$, the incidence of $P$. longicolla growing on the APDA was recorded.

From the seed plating data in 2006, 122 PIs without seed infection were selected and field screened under natural infection in Stoneville, MS, USA, in 2007. On the basis of assays of naturally infected seeds from 2006 and 2007, 14 PIs were selected for further evaluation with Phomopsisinoculated and non-inoculated treatments in 2008 and 2009 (Table 1). PI 424324B was identified as the most PSD-resistant line. It had no Phomopsis infection in the seed plating assays from 2006, 2007, and 2008. In 2009, frequent rainfall during seed maturation led to high levels of seed infection by 


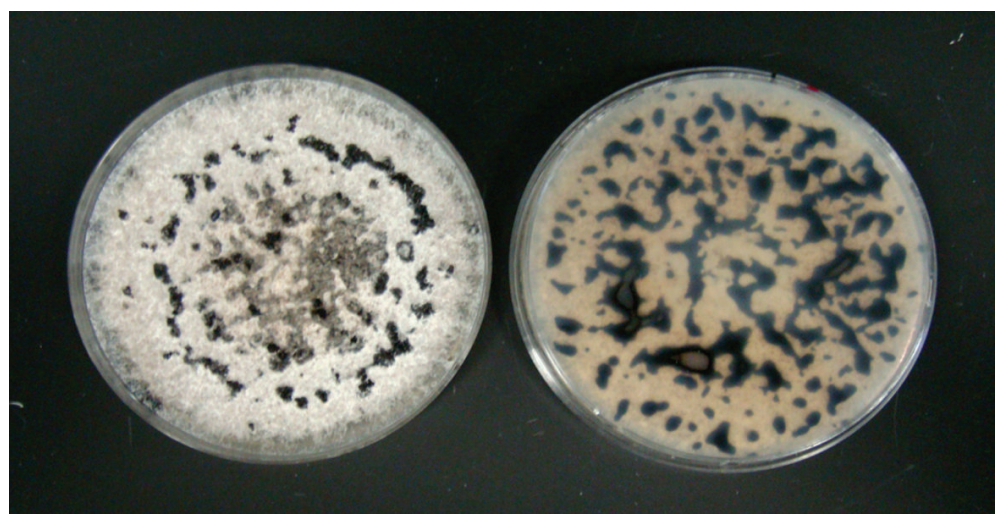

FIgURE 2: Phomopsis longicolla isolate MS10-6 collected from Mississippi Delta in 2010 and grown on acidified potato dextrose agar (pH 4.5) at $24^{\circ} \mathrm{C}$ for 50 days.

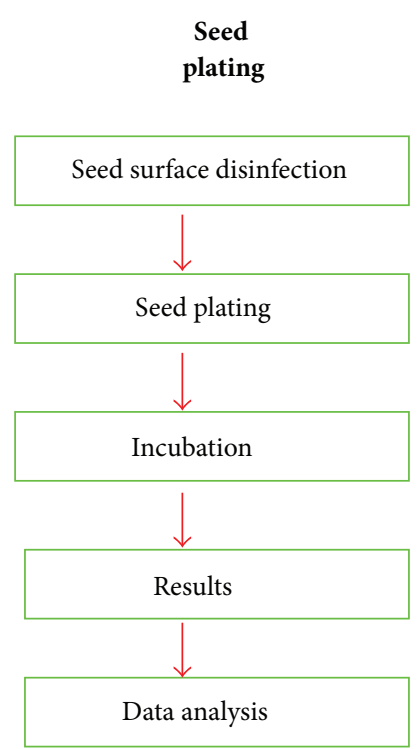

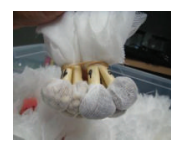

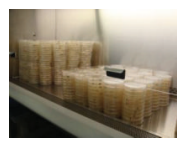

Used $0.5 \%$ sodium hypochlorite for $3 \mathrm{~min}$, rinsed in sterile distilled water $(3 \mathrm{x})$

Placed seeds on acidified potato dextrose agar ( $\mathrm{pH} 4.5$ ) in Petri dishes; five seeds per dish

Incubated at $24^{\circ} \mathrm{C}$ for five days

Take notes on Phomopsis-infected seeds

SAS: PROC corr and PROC mixed procedures

FIGURE 3: General procedure of seed plating.

Phomopsis (up to $80 \%$ ) and other fungal pathogens on most of the soybean lines tested in Stoneville, MS, USA. However, only $1 \%$ and $2 \%$ of the seeds from PI $424324 \mathrm{~B}$ were infected by $P$. longicolla in the non-inoculated and inoculated treatments, respectively [31]. In addition, PI 458130 was also resistant to PSD, with no seed infection from the naturally infected trials in 2006 and 2007, and less than 3\% Phomopsis seed infection in the 2008 and 2009 inoculated trails [31]. Eight of 14 accessions selected for resistance (PI 424324B, PI 458130, PI 506647, PI 567270C, PI 567381B, PI 567521, PI 567635, and PI 594858A) had an average percent seed infection of less than 5\% in 2008 and 2009, and this level was significantly less than that of 5601T, a well-adapted cultivar in Mississippi (Table 1). Some of these resistant accessions have been used to develop populations for genetics studies and breeding for resistance to PSD.
A 6-year project on "Screening germplasm and breeding for resistance to Phomopsis seed decay in soybean" has been funded by the United Soybean Board (USB), a group of farmer directors that administers the organization's soybean checkoff program, which seeks to strengthen soybean marketing, production technology, and research on new, valueadded uses. In this project, hundreds of soybean germplasm accessions representing 28 regions or origins and from MG III to V, breeding lines, and commercial cultivars collected around the world were screened for resistance to PSD in three states (Arkansas, Mississippi, and Missouri) of the USA starting in 2009. The seeds, 33 seeds $\mathrm{m}^{-1}$ of row, were planted in $3.04 \mathrm{~m}$ long single-row plots with a $0.96 \mathrm{~m}$ row spacing. The experimental design was a randomized complete block with four replications. The seeds were harvested from each plot when the plants were mature. The seeds from each plot were 
TABLE 1: Means of percent seed infected by Phomopsis longicolla of 16 soybean lines in replicated field tests with inoculated and non-inoculated treatments at Stoneville, Mississippi, in 2008 and 2009 [31].

\begin{tabular}{|c|c|c|c|c|c|c|c|}
\hline \multirow{2}{*}{ Soybean line } & \multicolumn{2}{|c|}{2008} & \multicolumn{2}{|c|}{2009} & \multicolumn{3}{|c|}{2008 and 2009} \\
\hline & Non & Inoc. & Non & Inoc. & Non & Inoc. & Mean \\
\hline $5601 \mathrm{~T}$ & 3.0 & 9.0 & 6.7 & 9.8 & 4.8 & 9.4 & 7.1 \\
\hline PI 304217 & 7.0 & 12.0 & 7.8 & 8.3 & 7.4 & 10.2 & 8.8 \\
\hline PI 398745 & 8.0 & 9.0 & 4.0 & 6.0 & 6.0 & 7.5 & 6.8 \\
\hline PI 399045 & 18.0 & 18.0 & 11.8 & 12.4 & 14.9 & 15.2 & 15.1 \\
\hline PI 408305 & 6.0 & 7.0 & 5.0 & 5.6 & 5.5 & 6.3 & 5.9 \\
\hline PI 424324B & 0.0 & 0.0 & 1.0 & 2.0 & 0.5 & 1.0 & 0.8 \\
\hline PI 458130 & 0.0 & 3.0 & 2.0 & 2.7 & 1.0 & 2.8 & 1.9 \\
\hline PI 506647 & 2.0 & 4.0 & 3.0 & 3.0 & 2.5 & 3.5 & 3.0 \\
\hline PI 507290 & 0.0 & 1.0 & 5.8 & 6.2 & 2.9 & 3.6 & 3.3 \\
\hline PI 549020 & 2.0 & 7.0 & 18.2 & 18.3 & 10.1 & 12.6 & 11.4 \\
\hline PI 549021B & 1.0 & 3.0 & 1.0 & 10.8 & 1.0 & 6.9 & 4.0 \\
\hline PI 567270C & 3.0 & 7.0 & 1.0 & 2.0 & 2.0 & 4.5 & 3.3 \\
\hline PI 567381B & 0.0 & 1.0 & 3.7 & 5.0 & 1.8 & 3.0 & 2.4 \\
\hline PI 567521 & 1.0 & 2.0 & 4.0 & 5.7 & 2.5 & 3.8 & 3.2 \\
\hline PI 567635 & 2.0 & 3.0 & 3.0 & 4.5 & 2.5 & 3.8 & 3.1 \\
\hline PI 594858A & 3.0 & 3.0 & 2.0 & 4.3 & 2.5 & 3.7 & 3.1 \\
\hline Mean & 3.5 & 5.6 & 5.0 & 6.7 & 4.2 & 6.1 & 5.2 \\
\hline $\operatorname{LSD}(P \leq 0.05)$ & 7.5 & 10.5 & 2.9 & 3.2 & 4.5 & 5.5 & 3.3 \\
\hline
\end{tabular}

Non: non-inoculated control sprayed with distilled water, Inoc.: inoculated with spore suspension of Phomopsis longicolla $\left(2 \times 10^{5}\right)$ at the R5 stage twice with a 10-day interval between inoculations, Mean: overall mean of non-inoculated and inoculated treatments across both 2008 and 2009, LSD: Fisher's protected least significant difference at $P \leq 0.05$.

tested for percent seed infected by Phomopsis spp., percent seed germination [42], and visual quality using a scale of 1 to 5 where $1=$ excellent (no bad/infected seed); $2=\operatorname{good}($ less than $10 \% \mathrm{bad} /$ infected seed); 3 = fair (11-30\% bad/infected seed); 4 $=$ poor $(31-50 \% \mathrm{bad} /$ infected seed $)$; and $5=$ very poor (more than $50 \% \mathrm{bad} /$ infected seed). Factors considered in estimating seed quality were seed wrinkling, molding, mottling, and discoloration. Frequent rainfall during seed maturation led to high levels of seed infection by a number of fungi. Significant differences in seed infection by Phomopsis spp. were observed among soybean lines with some lines having no infection, while others had infection levels as high as $90 \%$ [43-45]. These differences between lines were also reflected in visual seed quality and seed germination [43-45]. Soybean lines with low infection incidences, good visual quality, and high germination rates at all locations have potential to be resistant to PSD. Further tests of those lines are under progress.

Besides evaluating germplasm lines, 50 soybean cultivars were planted at Stoneville, Mississippi, to determine their reaction to PSD in 2007 [46]. Two lines, SS93-6012 and SS936181, previously reported to be PSD-resistant in Missouri were included [19], and the cultivars Hill and Williams 82 were used as susceptible checks. The seeds of soybean lines selected for planting were generally healthy. Of 50 lines tested, six lines had $100 \%$ germination, 30 lines had germination rates ranging from $80 \%$ to $97 \%$, and 12 lines had rates ranging from $63 \%$ to $77 \%$. Two lines had germination rates of $50 \%$ and $53 \%$, respectively. In the seed plating assay of non-inoculated seed, 37 lines had no $P$. longicolla-infected seed and 10 and three lines had $P$. longicolla incidences of 3\% and 7\%, respectively. Incidence of $P$. longicolla in seed from inoculated field plots differed significantly $(P \leq 0.05)$ ranging from $6 \%$ to $50 \%$ among soybean lines. Several soybean cultivars with lower disease incidence than the PSD resistant lines SS93-6181 and SS93-6013 were identified [46].

To date, at least 28 soybean lines have been reported to have certain levels of PSD resistance (Table 2). However, some resistant lines identified in other regions were susceptible in Arkansas, Mississippi, or Missouri, USA (Li et al., unpublished). It is not known if there is the possibility of diversity between populations of the pathogen in different locations, but there is a need to identify new sources of resistance to PSD.

\section{Inheritance of Resistance to Phomopsis Seed Decay}

Inheritance of resistance to PSD has been studied in several soybean lines including PI 417479, MO/PSD-0259, PI 80837, and PI 360841 (Table 1). In all cases, PSD resistance was characterized as qualitative traits and conditioned by major dominant genes [17, 18, 47-49]. However, allelism of PSD resistance is still not clear; therefore, no gene symbol has been assigned for PSD resistance yet.

Soybean PI 417479 was identified as a source of resistance to PSD from screening approximately 3,000 soybean introductions in MGs III and IV from 1983 through 1985 at the 
TABLE 2: A list of reported sources of resistance to Phomopsis seed decay.

\begin{tabular}{|c|c|c|}
\hline & Soybean line & Reference \\
\hline 1 & PI 548438 (Arksoy) & [17] \\
\hline 2 & PI 80837 & [36], [37] \\
\hline 3 & PI 82264 & {$[38]$} \\
\hline 4 & PI $88264^{*}$ & [17] \\
\hline 5 & PI 181550 & [39] \\
\hline 6 & PI 200501 & {$[40]$} \\
\hline 7 & PI 200510 & {$[17]$} \\
\hline 8 & PI 204331 & http://www.soydiseases.illinois.edu/ \\
\hline 9 & PI 205089 & http://www.soydiseases.illinois.edu/ \\
\hline 10 & PI 205907 & http://www.soydiseases.illinois.edu/ \\
\hline 11 & PI 205908 & http://www.soydiseases.illinois.edu/ \\
\hline 12 & PI 205912 & http://www.soydiseases.illinois.edu/ \\
\hline 13 & PI 209908 & {$[17]$} \\
\hline 14 & PI $219635^{*}$ & http://www.soydiseases.illinois.edu/ \\
\hline 15 & PI 227687 & [17] \\
\hline 16 & PI 229358 & {$[17]$} \\
\hline 17 & PI 259539 & http://www.soydiseases.illinois.edu/ \\
\hline 18 & PI 279088 & http://www.soydiseases.illinois.edu/ \\
\hline 19 & PI 341249 & http://www.soydiseases.illinois.edu/ \\
\hline 20 & PI 360835 & http://www.soydiseases.illinois.edu/ \\
\hline 21 & PI 360841 & {$[36]$} \\
\hline 22 & PI 385942 & http://www.soydiseases.illinois.edu/ \\
\hline 23 & PI 417419 & {$[36]$} \\
\hline 24 & PI $423903^{* *}$ & http://www.soydiseases.illinois.edu/ \\
\hline 25 & PI 562694 & {$[41]$} \\
\hline 26 & PI 424324B & {$[31]$} \\
\hline 27 & PI 458130 & {$[31]$} \\
\hline 28 & PI 567381B & [31] \\
\hline
\end{tabular}

${ }^{*}$ Named/assigned by the authors (see reference), not the accession number of the USDA Soybean Germplasm Collection.

${ }^{* *}$ Equal to PI 385942 (personal communication with Dr. Randy Nelson).

Agronomy Research Center of the University of Missouri, Columbia, MO, USA, and at the Isabela Substation of the University of Puerto Rico at Mayaguez [36]. To study the inheritance of PSD resistance in PI 417479, crosses were made between PI 417419 and two PSD-susceptible genotypes [49]. By analyzing PSD incidence on plants from five generations $\left(\mathrm{F}_{1}, \mathrm{~F}_{2}, \mathrm{~F}_{3}, \mathrm{BC}_{1}\right.$, and $\mathrm{BC}_{2}$, in which $\mathrm{BC}_{1}$ represented a backcross between the $\mathrm{F}_{1}$ and the resistant parent and $\mathrm{BC}_{2}$ represented a backcross between the $F_{1}$ and the susceptible parents), it was concluded that the PSD resistance in PI 417479 was controlled by two complementary dominant nuclear genes. The two resistance genes can thus be transferred using a backcross procedure in a breeding program [49].

It was reported that the PSD-resistant line MO/PSD-0259 derived its resistance from PI 417479 [18]. PI 80837 had low levels of PSD infection in field trials [37] and also exhibited resistance to soybean mosaic virus and purple seed stain [50-52]. To characterize the inheritance of PSD resistance in PI 80837 and to determine if it differs from resistance in MO/PSD-0259, PI 80837 was crossed with two PSDsusceptible lines Agripro 350 (AP350) and PI 9113, and with MO/PSD-0259 [18] (Table 3). The derived genetic populations were screened in the field and Phomopsis infection was assayed by plating seed. Results showed that seed infection of reciprocal $F_{1}$ plants of AP350 × PI 80837 was not different from that of PI 80837. Data from $\mathrm{F}_{2}$ populations of AP350 $\times$ PI 80837 and PI $91113 \times$ PI 80837 and $\mathrm{F}_{2: 3}$ lines from AP350 $\times$ PI 80837 fit yhe models for a single dominant gene in PI 80837 that confers PSD resistance. Likewise, $\mathrm{F}_{2}$ population data from AP350 $\times$ MO/PSD-0259 fit a model for single dominant gene resistance in MO/PSD-0259. However, data from an $\mathrm{F}_{2}$ population and $\mathrm{F}_{2: 3}$ lines of $\mathrm{PI} 80837 \times \mathrm{MO} / \mathrm{PSD}$ 0259 fit a model for two different dominant genes. Based on those results, Jackson et al. [18] concluded that PSD resistance in PI 80837 is conferred by a single dominant gene under nuclear control that is different from the gene in MO/PSD0259.

Studies on the inheritance of PSD resistance in soybean PI 360841 were conducted to test populations developed from the crosses between PI 360841 and two PSD-susceptible (S) genotypes, Agripro 350 (AP350) and PI 91113 (Figure 4), to determine the number of genes for PSD resistance [48]. Other crosses were made between PI 360841 and the PSDresistant (R) parents MO/PSD-0259 and PI 80837 to test the allelic relationships of the resistance genes [48]. Seeds from the parents and the $\mathrm{F}_{2}$ population were assayed for Phomopsis infection. Chi-square analysis of $\mathrm{F}_{2}$ data from the resistant $\times$ susceptible crosses indicated a good fit to a $9 \mathrm{R}: 7 \mathrm{~S}$ model for two complementary dominant genes conferring PSD resistance in PI 360841. $\mathrm{F}_{2}$ data from MO/PSD-0259 $\times$ PI 360841 showed a good fit to a 57R:7S model for two complementary dominant genes from PI 360841 and a different dominant gene from MO/PSD-0259. Since there was no apparent segregation for resistance in the $\mathrm{F}_{2}$ population derived from PI $360841 \times$ PI 80837, except for one suspicious susceptible plant, it suggested that one of the genes in PI 360841 is allelic to a PSD resistance gene in PI 80837 [48]. This was the first report of a new gene in PI 360841 for PSD resistance. This gene, along with other different PSDresistance genes in MO/PSD-0259 and PI 80837, is useful to breeders for developing lines with a high level of resistance to PSD. Further studies have identified simple sequence repeat (SSR) markers linked to genes for PSD resistance in PI 80837 and MO/PSD-0259. Jackson et al. (2009) reported that PSD resistance in MO/PSD-0259 and PI 80837 is controlled by two different single dominant genes [47]. The gene in PI 80837 is located in the vicinity of Sat 177 (4.3 cM) and Sat_342 (15.8 cM) on molecular linkage group (MLG) B2 (chromosome 14). The gene that conditions resistance in MO/PSD-0259 is linked to Sat_317 (5.9 cM) and Sat_120 (12.7 cM) on MLG F (chromosome 13). Identification of these loci and markers linked to them will facilitate marker-assisted selection in breeding programs. 
TABLE 3: Genetics of resistance to Phomopsis seed decay in soybean.

\begin{tabular}{|c|c|c|c|c|}
\hline Crosses & Type & Generation & Ratio & Reference \\
\hline AP350 $\times$ PI 80837 & $\mathrm{~S} \times \mathrm{R}$ & $\mathrm{F}_{2}$ & $3 \mathrm{R}: 1 \mathrm{~S}$ & {$[18,47]$} \\
\hline PI $91113 \times$ PI 80837 & $\mathrm{~S} \times \mathrm{R}$ & $\mathrm{F}_{2}$ & $3 \mathrm{R}: 1 \mathrm{~S}$ & {$[18]$} \\
\hline AP $350 \times$ MO/PSD-0259 & $\mathrm{S} \times \mathrm{R}$ & $\mathrm{F}_{2}$ & $3 \mathrm{R}: 1 \mathrm{~S}$ & {$[18]$} \\
\hline AP350 × PI 80837 & $\mathrm{~S} \times \mathrm{R}$ & $\mathrm{F}_{2: 3}$ & $1 \mathrm{R}: 2 \mathrm{H}: 1 \mathrm{~S}$ & {$[18]$} \\
\hline PI $80837 \times$ MO/PSD-0259 & $\mathrm{R} \times \mathrm{R}$ & $\mathrm{F}_{2}$ & $15 \mathrm{R}: 1 \mathrm{~S}$ & {$[18]$} \\
\hline PI $80837 \times$ MO/PSD-0259 & $\mathrm{R} \times \mathrm{R}$ & $\mathrm{F}_{2: 3}$ & $7 \mathrm{R}: 8 \mathrm{H}: 1 \mathrm{~S}$ & {$[18]$} \\
\hline PI $360841 \times$ AP350 & $\mathrm{R} \times \mathrm{S}$ & $\mathrm{F}_{2}$ & 9R:7S & {$[48]$} \\
\hline PI $91113 \times$ PI 360841 & $\mathrm{~S} \times \mathrm{R}$ & $\mathrm{F}_{2}$ & $9 \mathrm{R}: 7 \mathrm{~S}$ & {$[48]$} \\
\hline MO/PSD-0259 × PI 360841 & $\mathrm{R} \times \mathrm{R}$ & $\mathrm{F}_{2}$ & 57R:7S & {$[48]$} \\
\hline PI $360841 \times$ PI 80837 & $\mathrm{R} \times \mathrm{R}$ & $\mathrm{F}_{2}$ & $63: 1 S$ & {$[48]$} \\
\hline PI $417479 \times$ AP350 & $\mathrm{R} \times \mathrm{S}$ & $\mathrm{F}_{2}$ & $3 \mathrm{R}: 1 \mathrm{~S}$ & {$[49]$} \\
\hline PI $417479 \times$ AP350 & $\mathrm{R} \times \mathrm{S}$ & $\mathrm{F}_{3}$ & $5 \mathrm{R}: 3 \mathrm{~S}$ & {$[49]$} \\
\hline$(\mathrm{PI} 417479 \times \mathrm{AP} 350) \times \mathrm{AP} 350$ & $(\mathrm{R} \times \mathrm{S}) \times \mathrm{S}$ & $\mathrm{BC}_{1}$ & $1 \mathrm{R}: 1 \mathrm{~S}$ & {$[49]$} \\
\hline PI $417479 \times$ PI 91113 & $\mathrm{R} \times \mathrm{S}$ & $\mathrm{F}_{2}$ & $3 \mathrm{R}: 1 \mathrm{~S}$ & {$[49]$} \\
\hline PI $417479 \times$ PI 91113 & $\mathrm{R} \times \mathrm{S}$ & $\mathrm{F}_{3}$ & $5 \mathrm{R}: 3 \mathrm{~S}$ & {$[49]$} \\
\hline$(\mathrm{PI} 417479 \times$ PI 91113) $\times$ PI 91113 & $(\mathrm{R} \times \mathrm{S}) \times \mathrm{S}$ & $\mathrm{BC}_{1}$ & $1 \mathrm{R}: 1 \mathrm{~S}$ & [49] \\
\hline
\end{tabular}

$\mathrm{R}$ : resistant, S: susceptible, $\mathrm{H}$ : heterozygous and segregating for PSD reaction, $\mathrm{BC}$ : backcross.

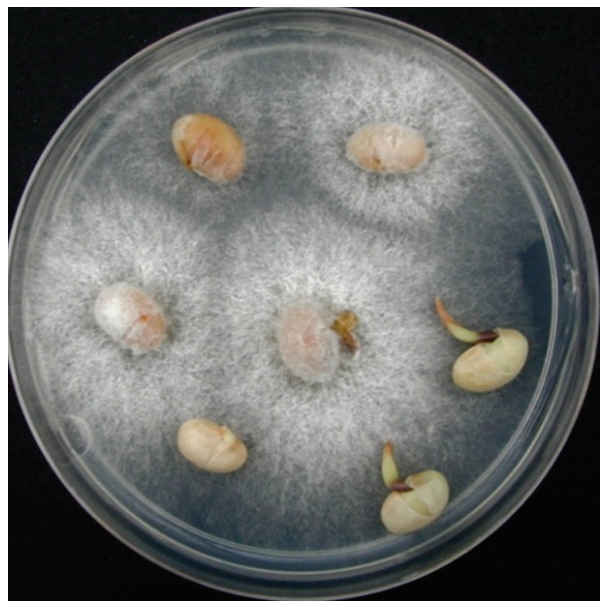

(a)

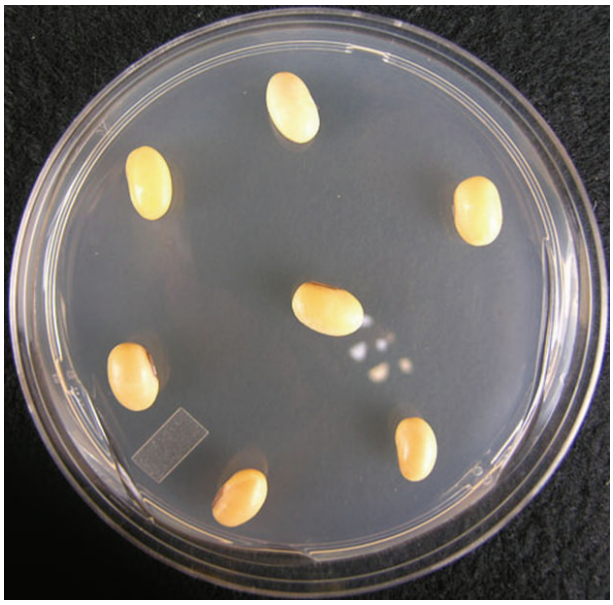

(b)

FIgURE 4: Susceptible parent PI 91113 and resistant parent PI 360841 with and without Phomopsis spp. infection, respectively.

\section{Conclusions}

Phomopsis seed decay (PSD) of soybean causes poor seed quality and suppresses yield in most soybean-growing countries. The disease is caused primarily by the fungal pathogen Phomopsis longicolla along with other Phomopsis and Diaporthe spp. Infected seeds range from symptomless to shriveled, elongated, cracked, and often appear chalky white. Seed quality is poor due to reduction in seed viability and oil content, alteration of seed composition, and increased frequencies of moldy and/or split beans. Hot and humid environments, especially during the period from pod fill through harvest, favor pathogen growth and disease development. The use of resistant cultivars is the most effective method for controlling PSD. Extensive screening for PSD resistance has resulted in the identification of resistant sources. MO/PSD0259 carries a single dominant gene for PSD resistance derived from PI 417479, whereas resistance in PI 80837 is conferred by a different gene. PI 360841 carries two complementary dominant genes for PSD resistance; both are different from the gene in MO/PSD-0259 but one of them maps to the same region as the gene in PI 80837. Simple sequence repeat (SSR) markers linked to PSD resistance genes in PI 80837 and MO/PSD-0259 have been identified. These SSR markers should be useful in selection for resistant genotypes in breeding programs. 


\section{Acknowledgments}

The authors appreciate the support of the United Soybean Board for the research Projects \#9261 (2009-2012) and \#2261 (2012-2015) on "Screening germplasm and breeding for resistance to Phomopsis seed decay in soybean," and the Mississippi Soybean Promotion Board for the research on "Identification of soybean varieties with resistance to Phomopsis seed decay to enhance soybean seed quality" as well as the support from Drs. John Rupe, Allen Wrather, and Gabe Sciumbato for their collaboration in the projects. The research was also supported by USDA-ARS Project 6402-21220-010-00D. Special thanks go to Drs. Richard Joost, Stephen Muench, Kelly Whiting, Larry G. Heatherly, and Lawrence Young for the valuable discussion about the research on Phomopsis seed decay. The mention of a trademark or proprietary product does not constitute a guarantee or warranty of the product by the US Department of Agriculture and does not imply approval or the exclusion of other products that may also be suitable.

\section{References}

[1] T. W. Hobbs, A. F. Schmitthenner, and G. A. Kuter, "A new Phomopsis species from soybean," Mycologia, vol. 77, no. 4, pp. 535-544, 1985.

[2] S. Li, "Phomopsis seed decay of soybean," in SoybeanMolecular Aspects of Breeding, A. Sudaric, Ed., pp. 277-292, InTech, Vienna, Austria, 2011.

[3] J. B. Sinclair, "Phomopsis seed decay of soybeans-a prototype for studying seed disease," Plant Disease, vol. 77, pp. 329-334, 1993.

[4] P. R. Hepperly and J. B. Sinclair, "Quality losses in Phomopsisinfected soybean seeds," Phytopathology, vol. 68, pp. 1684-1687, 1978.

[5] J. C. Rupe, "Effects of temperature on the rate of infection of soybean seedlings by Phomopsis longicolla," Canadian Journal of Plant Pathology, vol. 12, no. 1, pp. 43-47, 1990.

[6] J. C. Rupe and R. S. Ferriss, "Effects of pod moisture on soybean seed infection by Phomopsis sp.," Phytopathology, vol. 76, pp. 273-277, 1986.

[7] J. A. Wrather, J. G. Shannon, W. E. Stevens, D. A. Sleper, and A. P. Arelli, "Soybean cultivar and foliar fungicide effects on Phomopsis sp. seed infection," Plant Disease, vol. 88, no. 7, pp. 721-723, 2004.

[8] A. J. Balducchi and D. C. McGee, "Environmental factors influencing infection of soybean seeds by Phomopsis and Diaporthe species during seed maturation," Plant Disease, vol. 71, pp. 209212, 1987.

[9] K. T. Kmetz, C. W. Ellett, and A. F. Schmitthenner, "Soybean seed decay: sources of inoculum and nature of infection," Phytopathology, vol. 69, pp. 798-801, 1979.

[10] G. L. Hartman, J. B. Sinclair, and J. C. Rupe, Compendium of Soybean Diseases, American Phytopathological Society, St. Paul, Minn, USA, 4th edition, 1999.

[11] J. A. Wrather, D. A. Sleper, W. E. Stevens, J. G. Shannon, and R. F. Wilson, "Planting date and cultivar effects on soybean yield, seed quality, and Phomopsis sp. seed infection," Plant Disease, vol. 87, no. 5, pp. 529-532, 2003.

[12] R. E. Baird, S. Abney, and B. G. Mullinix, "Fungi associated with pods and seeds during the R6 and R8 stages of four soybean cultivars in Southwestern Indiana," Phytoprotection, vol. 82, no. 1, pp. 1-11, 2001.

[13] J. A. Wrather and S. R. Koenning, "Effects of diseases on soybean yields in the United States 1996 to 2007," Plant Health Progress, 2009.

[14] L. G. Heatherly, "Early soybean production system (ESPS)," in Soybean Production in the Midsouth, L. G. Heatherly and H. F. Hodges, Eds., pp. 103-118, CRC Press, Boca Raton, Fla, USA, 1999.

[15] W. L. Mayhew and C. E. Caviness, "Seed quality and yield of early-planted, short-season soybean genotypes," Agronomy Journal, vol. 86, no. 1, pp. 16-19, 1994.

[16] S. R. Koenning, "Southern United States soybean disease loss estimate for 2009," in Proceedings of the Southern Soybean Disease Workers 37th Annual Meeting, p. 1, Pensacola Beach, Fla, USA, 2010.

[17] H. C. Minor, E. A. Brown, and M. S. Zimmerman, "Developing soybean varieties with genetic resistance to Phomopsis spp.", Journal of the American Oil Chemists' Society, vol. 72, no. 12, pp. 1431-1434, 1995.

[18] E. W. Jackson, P. Fenn, and P. Chen, "Inheritance of resistance to Phomopsis seed decay in soybean PI 80837 and MO/PSD-0259 (PI 562694)," Crop Science, vol. 45, no. 6, pp. 2400-2404, 2005.

[19] M. S. Pathan, K. M. Clark, J. A. Wrather et al., "Registration of soybean germplasm SS93-6012 and SS93-6181 resistant to Phomopsis seed decay," Journal of Plant Registrations, vol. 3, no. 1, pp. 91-93, 2009.

[20] K. W. Roy, B. C. Keith, and C. H. Andrews, "Resistance of hard seeded soybean lines to seed infection by Phomopsis, other fungi and soybean mosaic virus," Canadian Journal of Plant Pathology, vol. 16, no. 2, pp. 122-128, 1994.

[21] S. Li, P. Chen, G. L. Hartman, J. Smith, and R. Nelson, "Research highlights on soybean Phomopsis seed decay in the US: pathogen characterization, germplasm screening, and genetic resistance," in Proceedings of the 8th Abstracts of 2009 World Soybean Research Conference, pp. 91-92, Beijing, China, August 2009.

[22] R. K. Velicheti, C. Lamison, L. M. Brill, and J. B. Sinclair, "Immunodetection of Phomopsis species in asymptomatic soybean plants," Plant Disease, vol. 77, pp. 70-73, 1993.

[23] M. M. Kulik and J. B. Sinclair, "Phomopsis seed decay," in Compendium of Soybean Diseases, G. L. Hartman, J. B. Sinclair, and J. C. Rupe, Eds., pp. 31-32, American Phytopathological Society, St. Paul, Minn, USA, 1999.

[24] A. Mengistu, L. Castlebury, R. Smith, and J. Ray, "Seasonal progress of Phomopsis longicolla infection on soybean plant parts and its relationship to seed quality," Plant Disease, vol. 93, no. 10, pp. 1009-1018, 2009.

[25] A. G. Xue, M. J. Morrison, E. Cober et al., "Frequency of isolation of species of Diaporthe and Phomopsis from soybean plants in Ontario and benefits of seed treatments," Canadian Journal of Plant Pathology, vol. 29, no. 4, pp. 354-364, 2007.

[26] T. C. Harrington, J. Steimel, F. Workneh, and X. B. Yang, "Molecular identification of fungi associated with vascular discoloration of soybean in the North Central United States," Plant Disease, vol. 84, no. 1, pp. 83-89, 2000.

[27] S. G. Lehman, "Pod and stem blight of the soybean," Annals of the Missouri Botanical Garden, vol. 10, no. 2, pp. 111-178, 1923.

[28] J. B. Sinclair, "Diaporthe-Phomopsis," in Compendium of Soybean Diseases, G. L. Hartman, J. B. Sinclair, and J. C. Rupe, Eds., p. 31, American Phytopathological Society, St. Paul, Minn, USA, 1999. 
[29] G. N. Agrios, Plant Pathology, Academic Press, San Diego, Calif, USA, 1999.

[30] M. C. Shurtleff and C. W. Averre III, Glossary of PlantPathological Terms, American Phytopathological Society, St. Paul, Minn, USA, 1997.

[31] S. Li, J. Smith, and R. Nelson, "Resistance to Phomopsis seed decay identified in maturity group V soybean plant introductions," Crop Science, vol. 51, no. 6, pp. 2681-2688, 2011.

[32] S. Li, G. L. Hartman, and D. L. Boykin, "Aggressiveness of Phomopsis longicolla and other Phomopsis spp. on soybean," Plant Disease, vol. 94, no. 8, pp. 1035-1040, 2010.

[33] S. Li, C. A. Bradley, G. L. Hartman, and W. L. Pedersen, "First report of Phomopsis longicolla from velvetleaf causing stem lesions on inoculated soybean and velvetleaf plants," Plant Disease, vol. 85, no. 9, p. 1031, 2001.

[34] A. W. Zhang, G. L. Hartman, L. Riccioni, W. D. Chen, R. Z. $\mathrm{Ma}$, and W. L. Pedersen, "Using PCR to distinguish Diaporthe phaseolorum and Phomopsis longicolla from other soybean fungal pathogens and to detect them in soybean tissues," Plant Disease, vol. 81, no. 10, pp. 1143-1149, 1997.

[35] A. W. Zhang, L. Riccioni, W. L. Pedersen, K. P. Kollipara, and G. L. Hartman, "Molecular identification and phylogenetic grouping of Diaporthe phaseolorum and Phomopsis longicolla isolates from soybean," Phytopathology, vol. 88, no. 12, pp. 13061314, 1998.

[36] E. A. Brown, H. C. Minor, and O. H. Calvert, "A soybean genotypes resistant to Phomopsis seed decay," Crop Science, vol. 27, no. 5, pp. 895-898, 1987.

[37] L. D. Ploper, T. S. Abney, and K. W. Roy, "Influence of soybean genotype on rate of seed maturation and its impact on seedborne fungi," Plant Disease, vol. 76, pp. 287-292, 1992.

[38] H. J. Walters and C. E. Caviness, "Breeding for improved soybean seed quality," Arkansas Farm Research, vol. 22, article 5, 1973.

[39] K. L. Athow, "Fungal diseases," in Soybeans: Improvement, Production, and Uses, J. R. Wlcox, Ed., vol. 16 of Agronomy Monograph, pp. 687-727, ASA, CSSA, and SSSA, Madison, Wis, USA, 2nd edition, 1987.

[40] J. P. Ross, "Registration of eight soybean germplasm lines resistant to seed infection by Phomopsis spp.," Crop Science, vol. 26, article 210, 1986.

[41] H. C. Minor, E. A. Brown, B. L. Doupnik Jr., R. W. Elmore, and M. S. Zimmerman, "Registration of Phomopsis seed decayresistant soybean germplasm MO/PSD-0259," Crop Science, vol. 33, no. 5, p. 1105, 1993.

[42] L. O. Copeland, "Rules for testing seeds," in Association of Official Seed Analysis, Stone Printing, Lansing, Mich, USA, 1981.

[43] S. Li, P. Chen, J. Rupe, and A. Wrather, "Reaction of maturity group V soybean plant introductions to Phomopsis seed decay in Arkansas, Mississippi, and Missouri, 2009," Plant Disease Management Reports, vol. 4, Article ID ST034, 2010.

[44] S. Li, J. Rupe, P. Chen, and A. Wrather, "Reaction of maturity group IV soybean plant introductions to Phomopsis seed decay in Arkansas, Mississippi, and Missouri, 2009," Plant Disease Management Reports, vol. 4, Article ID ST035, 2010.

[45] S. Li, A. Wrather, J. Rupe, and P. Chen, "Reaction of maturity group III soybean plant introductions to Phomopsis seed decay in Arkansas, Mississippi, and Missouri, 2009," Plant Disease Management Reports, vol. 4, Article ID ST036, 2010.

[46] S. Li, D. Boykin, G. Sciumbato, A. Wrather, G. Shannon, and D. Sleper, "Reaction of soybean cultivars to Phomopsis seed decay in the Mississippi Delta, 2007," Plant Disease Management Reports, 2009.

[47] E. W. Jackson, C. Feng, P. Fenn, and P. Chen, "Genetic mapping of resistance to Phomopsis seed decay in the soybean breeding line MO/PSD-0259 (PI562694) and plant introduction 80837," Journal of Heredity, vol. 100, no. 6, pp. 777-783, 2009.

[48] S. Smith, P. Fenn, P. Chen, and E. Jackson, "Inheritance of resistance to Phomopsis seed decay in PI 360841 soybean," Journal of Heredity, vol. 99, no. 6, pp. 588-592, 2008.

[49] M. S. Zimmerman and H. C. Minor, "Inheritance of Phomopsis seed decay resistance in soybean PI 417479," Crop Science, vol. 32, pp. 96-100, 1993.

[50] G. R. Buss, T. J. Smith, and H. M. Camper, "Registration of Ware soybean cultivar," Crop Science, vol. 19, article 564, 1979.

[51] K. W. Roy and T. S. Abney, "Colonization of pods and infection of seeds by Phomopsis longicolla in susceptible and resistant soybean lines inoculated in the greenhouse," Canadian Journal of Plant Pathology, vol. 10, no. 4, pp. 317-320, 1988.

[52] J. R. Wilcox, F. A. Laviolette, and R. J. Martin, "Heritability of purple seed stain resistance in soybean," Crop Science, vol. 15, no. 4, pp. 525-526, 1975. 


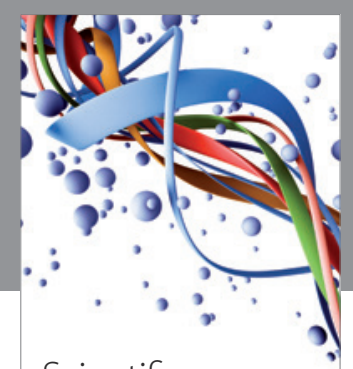

Scientifica
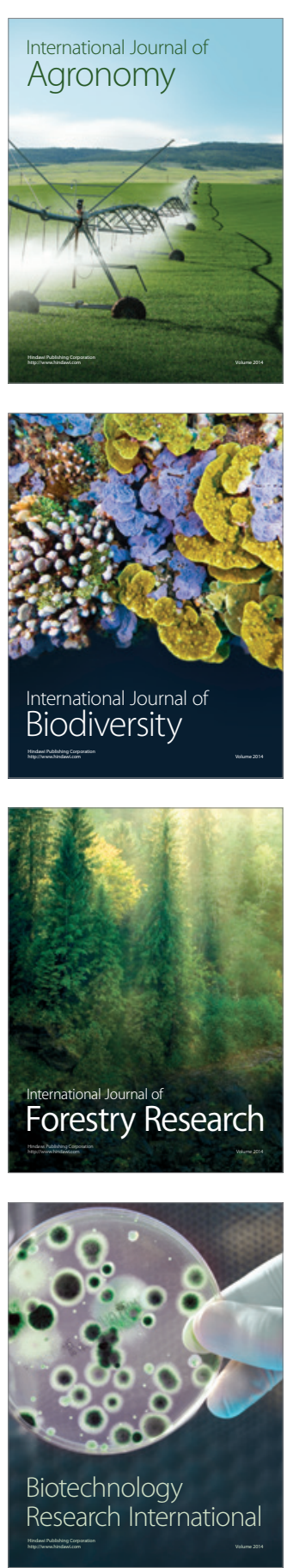
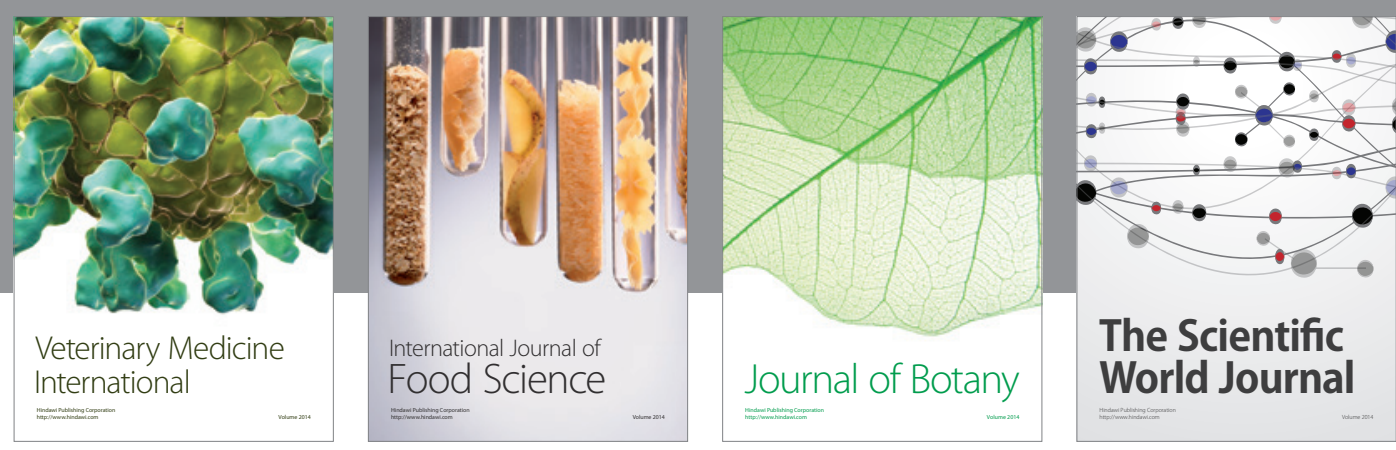

The Scientific World Journal
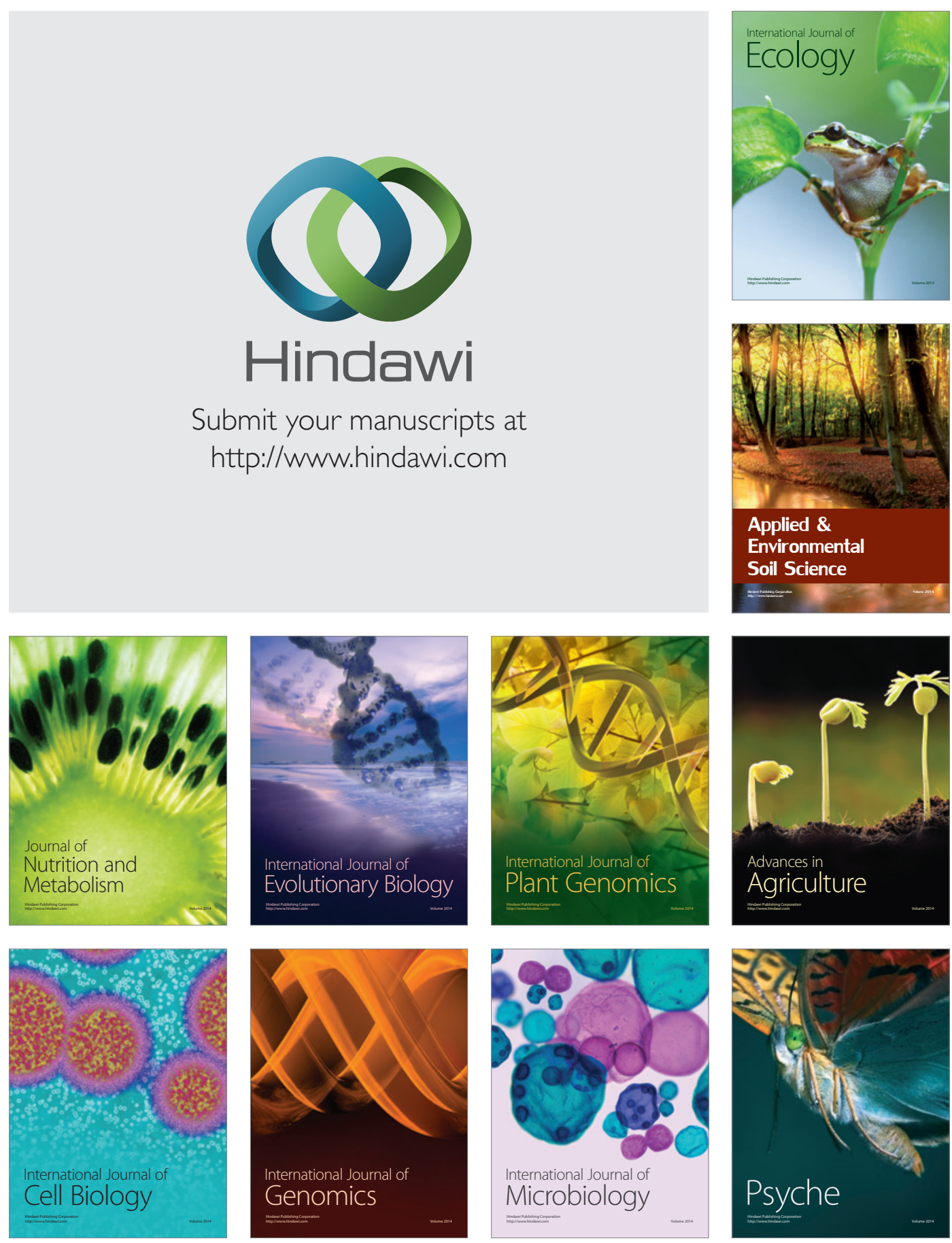